NOTE

\title{
Local population disappearance follows (20 yr after) cycle collapse in a pivotal ecological species
}

\author{
David K. A. Barnes*, Emma Verling, Anne Crook, Ian Davidson, Maria O'Mahoney \\ Department of Zoology and Animal Ecology, University College Cork, Cork, Ireland
}

\begin{abstract}
Populations of the echinoid Paracentrotus lividus have undergone spectacular population fluctuations over the last $40 \mathrm{yr}$ at Lough Hyne, SW Ireland. Censuses in 2000 and 2001, reported here, show no individuals present in the South Basin of Lough Hyne, for what is believed to be, the first time since observations began in the late 1920s. As with many echinoids, $P$. lividus was considered to have a pivotal role in benthic ecology through control of algae by grazing. The discontinuation of $P$. lividus in South Basin of Lough Hyne is significant for 3 reasons. First, the database was 1 of the longest running censuses of a discrete echinoid population anywhere. Second, some corresponding environmental and population size structure data had been recorded over several decades. Third, P. lividus was very important in structuring the shallow benthic community of the oldest marine reserve in Europe.
\end{abstract}

KEY WORDS: Echinoids $\cdot$ Long-term monitoring $\cdot$ Paracentrotus lividus · Lough Hyne

$$
\text { Resale or republication not permitted }
$$$$
\text { without written consent of the publisher }
$$

Many populations of organisms have semi-regular cyclical patterns of abundance. In the cycles of some grazing animals, both the level of fluctuation and the environmental cause or effect can be spectacular. However, observation and scientific appreciation of such an event often requires long-term censuses as cycles may take place over a number of years (Dempster \& Lakhani 1979) or decades (MacLulick 1937, Elner \& Vadas 1990). At Lough Hyne changes in the population density of Paracentrotus lividus have been documented as exceeding $>4$ orders of magnitude (Kitching 1987, Barnes et al. 2001). Although observations have been made on the P. lividus population since

*Present address: Biological Sciences Division, British Antarctic Survey, Natural Environment Research Council, High Cross, Madingley Road, Cambridge CB3 OET, United Kingdom.E-mail: dkab@bas.ac.uk the 1920 s, the first proper censuses were only undertaken in the mid-1960s. Since the early 1980s, the apparent cycles have broken down and the population age/size structure has changed to become increasingly dominated by older individuals. Censuses of the years 2000 and 2001, reported here, were the first to reveal no individuals in the South Basin. Interdecadal boom and bust population patterns are known in sea urchins on American and European Atlantic coasts, alternately resulting in profuse and dense algal beds and 'barrens'.

Sea urchins are important at the community level as they are often principal grazers, preventing algal smothering of coral reefs in the tropics (Jackson 1997) and monospecies dominance of temperate rocky shallows (Kitching 1987). As a result they have often been described as 'keystone species' in the habitats where they are abundant. Presence of keystone species in a community have been considered as stabilising influences, such as the seastar Pisaster in mussel beds (Paine 1974), or of a destabilising nature, such as the seastar Acanthaster on coral reefs (Moran 1986). The keystone concept when applied to American sea urchins and their predators proved a hotbed of debate (Elner \& Vadas 1990). At Lough Hyne, SW Ireland, the sea urchin Paracentrotus lividus had a pivotal role in algal control (Kitching 1987) although it has never been demonstrated (through experimental manipulation) to be keystone. This note thus reports a population level phenomenon that has community level implications.

Data collection. Observers counted the entire visible population of Paracentrotus lividus at Lough Hyne in early summer. The population size censuses of the study species have, for data continuity, had to conform to original methodology (see Muntz et al. 1965, Kitching 1987). A boat was rowed around the periphery of 
Lough Hyne with 2 observers situated in the stern. The observers counted all $P$. lividus individuals visible through Perspex viewing boxes. As census data was based on observation of the entire population, measures of error could only be obtained by repeating the census. Repetition of the survey on subsequent days has shown observer and daily variability to be $<5 \%$, but was 0 in the 2 surveys (years 2000 and 2001) reported here. Snorkel based surveys have found considerably higher census values in the past (Barnes et al. 2001) but also reported identical values to boat surveys in 2000 and 2001.

Sixty years of boom and bust cycles ends in bust. Although Lough Hyne was Europe's first designated marine reserve in 1981, marine biological research had begun there much earlier in the 1920s. The focus then, and for much of the 1950s to 1980s, was on the ecological role of the sea urchin Paracentrotus lividus. When first studied, P. lividus dominated Lough Hyne's shallows in dense (>200 $\mathrm{m}^{-2}$ ) thickets (Renouf 1931) and, therefore, had a pivotal role in shaping ecological processes there (see Kitching 1987). Elsewhere, principally in the Mediterranean Sea, populations of the species have catastrophically declined, mostly as a direct result of overfishing (Southward \& Southward 1975). The Lough Hyne population may have been largely self-maintaining, as water movement is very low within much of Lough Hyne (thus particles have a long period of residence) and there is no other substantial nearby population. The $P$. lividus population was noted to be high in some years and low in others for a number of decades. Although censuses were started in the 1960s, they were only established with annual frequency in 1971 (Kitching 1987). The periods of high and low abundance seemed, prior to the early 1980s, to be clearly cyclical alternating from a total (South Basin) population of $10000 \mathrm{~s}$ to $100 \mathrm{~s}$ or 10 to $0.1 \mathrm{~m}^{-2}$. Fig. 1 illustrates the South Basin population changes from 1960 to 2001. Explanations for such cycles, as for other sea urchin populations, have been varied and difficult to test. The most recent theory, that of failed mass spawning connected to variability of the temperature of the sea surface (SST) and El Niño Southern Oscillation (ENSO) events (Barnes et al. 2001), is unlikely to explain the ultimate collapse of the population. There were persistently depressed maximal SSTs and ENSO events immediately prior to $P$. lividus population decreases from the 1960s to the early 1980s. When the South Basin P. lividus population only reached levels in the 100s, however, it showed no obvious relationship to external factors. In particular, in the south Basin of Lough Hyne, the population had also become fragmented into small pockets, more than $100 \mathrm{~m}$ apart, each of which shrank to 0 in the year 2000. That none was observed in 2001, in addition to the previous year, suggests that the population has finally disappeared.

Evidence for reduced numbers of recruits comes from 3 sources. First, mass spawning has rarely been seen in recent years. Second, plankton sampling from 1977 to 1981 (Minchin 1992), and more recently in 1998 and 1999, found more echinoplutei larvae in the water column in warm years (maximum SST $>17^{\circ} \mathrm{C}$ ) at Lough Hyne (Greenwood 2000). There have been few years when the sea temperature has been $>17^{\circ} \mathrm{C}$ since the

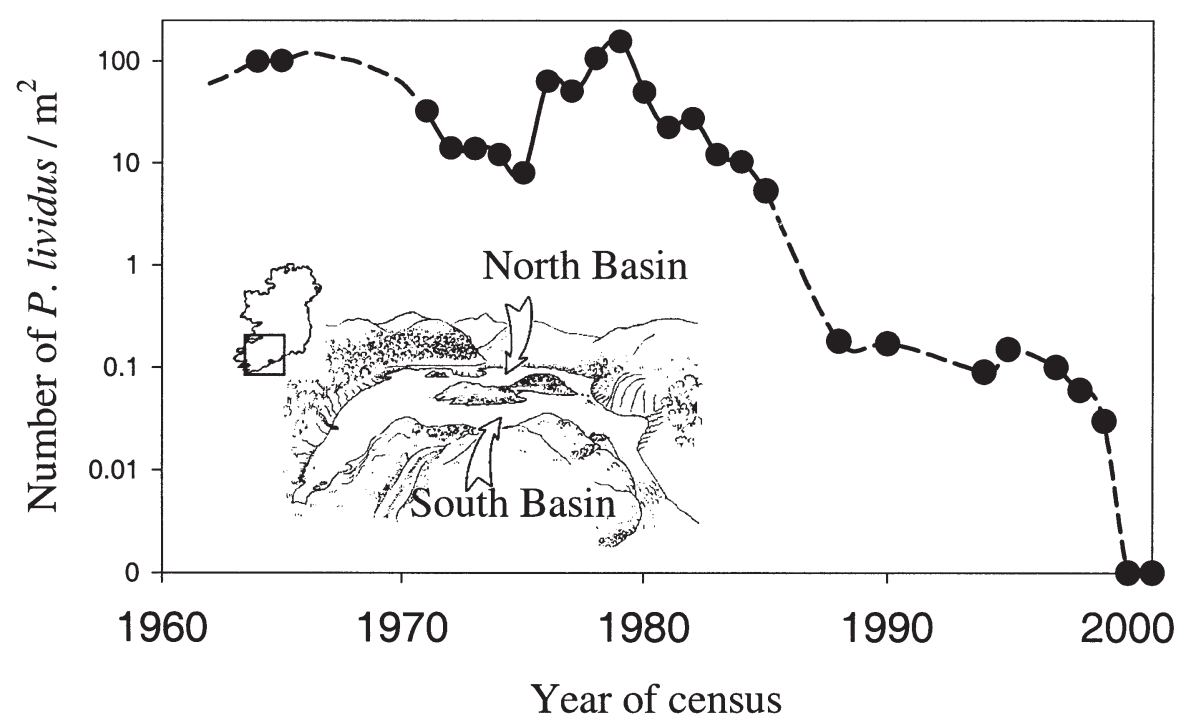

Fig. 1. Population fluctuation of Paracentrotus lividus in the South Basin of Lough Hyne. P. lividus census data from Muntz et al. (1965), Kitching (1987), Barnes et al. (2001) and present study (2000 and 2001 points). Data prior to the 1960s is not shown, as actual censuses were not recorded. Insert is the position of Lough Hyne in Ireland 
early 1980s (Barnes et al. 2001). Few echinoderm larvae were found in the South Basin in the 1998/1999 tows (Greenwood et al. 2000). Third, young 0+ cohort recruits were a major proportion of the population in 1977, but absent when sampled in this study. Blooms of various toxic dinoflagellate (such as Gyrodinium sp.) may have been responsible for mass sea urchin kills (including $P$. lividus) in the past both on American (Scheibling 1986) and Atlantic shores (Cross \& Southgate 1980). The virtually annual Lough Hyne red tides in recent years have, however, been composed of Noctiluca sp. (author's unpubl. data) and have had no associated sea urchin mortality.

The surveys of Lough Hyne's South Basin Paracentrotus lividus population have been important and unusual in that they represented a database including: (1) links as far back as the1920s, (2) a specific and ecologically important species population and (3) corresponding environmental parameters such as sea temperature. Whether (ENSO linked) depressed SSTs were the underlying cause of the major P. lividus population changes observed in the late 1950s, early 1970s and early 1980s will now be very difficult to establish. The $P$. lividus population of the North Basin, which has always been more substantial than that of the South Basin (considered too dense to survey), has shrunk to just a few 1000 individuals. They are, however, not fragmented and their location is exposed to the highest SSTs recorded in Lough Hyne. If the North Basin population of P. lividus also dwindles to local extinction, other species may follow and the change in 1 of the world's best and oldest studied local marine environments may become permanent.

Acknowledgements. The authors would like to thank the warden (at the time of the study), Declan O'Donnell, for permits to undertake research and the caretaker of Lough Hyne, John Bohane, for long-term commitment in support of the Lough Hyne environment.

Editorial responsibility: Otto Kinne (Editor), Oldendorf/Luhe, Germany

\section{LITERATURE CITED}

Barnes DKA, Crook AC, O'Mahoney M, Steele S, Maguire D (2001) Sea temperature variability and Paracentrotus lividus (Echinoidea) population fluctuations. J Mar Biol Assoc UK 81:359-360

Cross TF, Southgate T (1980) Mortalities of fauna of rocky substrates in south west Ireland associated with the occurrence of Gyrodinium aureolum blooms during autumn 1979. J Mar Biol Assoc UK 60:1071-1073

Dempster JP, Lakhani KH (1979) A population model for Cinnabar moth and its food plant, ragwort. J Anim Ecol:143-164

Elner RW, Vadas RL (1990) Inference in ecology: the sea urchin phenomenon in the northwestern Atlantic. Am Nat 136:108-125

Greenwood A (2000) The reproductive ecology of Echinoderms at Lough Hyne Marine Nature Reserve. PhD thesis, University College Cork

Greenwood A, Barnes DKA, O'Riordan RM (2000) Seasonality of echinoderm plankton in Lough Hyne marine nature reserve. Biol Environ 100B:171-180

Jackson JBC (1997) Reefs since Colombus. Coral Reefs 16:S23-S32

Kitching JA (1987) Ecological studies at Lough Hyne. Adv Ecol Res 17:115-186

MacLulick DA (1937) Fluctuation in numbers of the varying hare (Lepus americanus). University of Toronto Studies, Biology Series 43:1-136

Minchin D (1992) Multiple species, mass spawning events in an Irish sea lough: the effect of temperatures on spawning and recruitment of invertebrates. Invertebr Reprod Dev 22:229-238

Moran PJ (1986) The Acanthaster phenomenon. Oceanogr Mar Biol Annu Rev 24:379-480

Muntz L, Ebling FJ, Kitching JA (1965) The ecology of Lough Ine XIV. Predatory activity of large crabs. J Anim Ecol 34: $315-329$

Paine RT (1974) Intertidal community structure: experimental studies on the relationship between a dominant competitor and its principal predator. Oecologia 15:93-120

Renouf L (1931) Preliminary work of the new marine biological station (Lough Ine, Co. Cork). J Ecol 19:410-438

Scheibling RE (1986) Increased macroalgal abundance following mass mortalities of sea urchins (Strongylocentrotus droebachiensis) along the Atlantic coast of Nova Scotia. Oecologia 68:186-198

Southward AJ, Southward E (1975) The endangered urchins. New Sci 66:70-73

Submitted: August 9, 2001; Accepted: December 4, 2001 Proofs received from author(s): January 16, 2002 


\section{Erratum}

\section{High ammonium production from sediments in hypereutrophic shrimp ponds}

\section{Michele A. Burford, Andrew R. Longmore}

Mar Ecol Prog Ser 224:187-195, 2001

- On page 193, two data points were misplaced in Fig. 5. The corrected figure and legend are shown here.

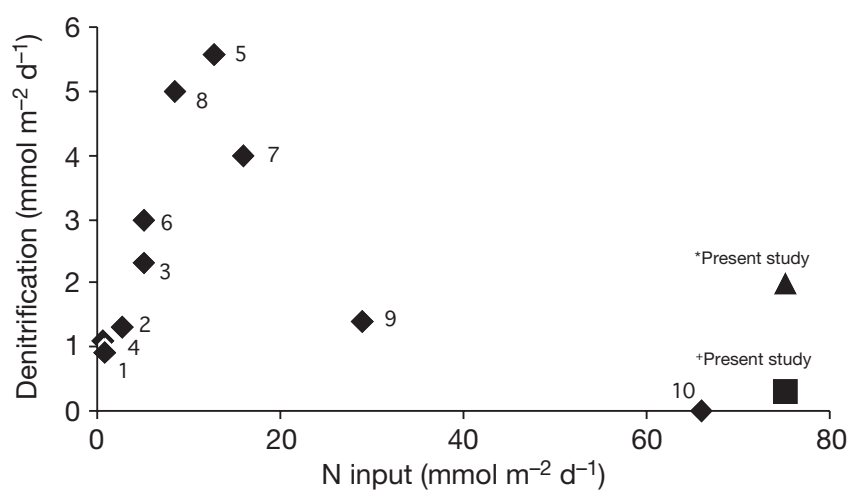

Fig. 5. Nitrogen $(\mathrm{N})$ input versus denitrification rates (mmol $\mathrm{m}^{-2} \mathrm{~d}^{-1}$ ) at various sites: ${ }^{1}$ Moreton Bay, Australia (acetylene block, slurry method, Dennison \& Abal 1999); ${ }^{2}$ Narragansett Bay, USA $;{ }^{3}$ Delaware Bay, USA; ${ }^{4}$ Baltic Sea $;{ }^{5}$ Tejo Estuary, Portugal $\left(\mathrm{N}_{2}\right.$ method except for Baltic Sea data where nitrate $\mathrm{NO}_{3}{ }^{-}$anomalies were used, Seitzinger 1988); ${ }^{6}$ Central Port Phillip Bay, Australia (benthic chamber method, Berelson et al. 1998); ${ }^{7}$ North Port Phillip Bay, Australia (benthic chamber method) ${ }^{8}$ Norsminde Fjord, Denmark (acetylene block, intact cores method, Jørgensen \& Sørensen 1988); ${ }^{9}$ Fish ponds (acetylene block, intact cores method, Hall et al. 1992); ${ }^{10}$ Fish cages (acetylene block, in situ method). ${ }^{*}$ Present study — acetylene block method; ${ }^{+}$Present study — inferred benthic flux 